\title{
Assessing the Benefits of the BPRS Bank Products Well Variety for the Economy of the Community
}

\author{
Dedy Arfiyanto $^{1 *}$, Isnani Yuli Andini ${ }^{2}$, Aprilina Susandini ${ }^{3}$, Nurdody Zakki ${ }^{1}$ \\ ${ }^{1}$ Managemet Study Program, Faculty of Economics and Business, University of Wiraraja \\ ${ }^{2}$ Accounting Study Program, Faculty of Economics and Business, University of Wiraraja \\ ${ }^{3}$ Entrepreneurship Study Program, Faculty of Economics and Business, University of Trunojoyo Madura \\ *Corresponding Author: Dedy Arfiyanto, Managemet Study Program, Faculty of Economics and \\ Business, University of Wiraraja, Indonesia
}

\begin{abstract}
Ar-Rahn financing or gold pawning products from Bank BPRS Bhakti Sumekar had been very popular lately and had became the most preferred financing alternative among the public, especially the Sumenep community. Ar-Rahn's financing was in great demand because the process very fast and practical. Bank BPRS Bhakti Sumekar was the first bank in Sumenep to introduce Rahn or a gold pawn in accordance with Islamic sharia. Based on the phenomena that exist in the field, this researcher knew more and more about the practice of implementing Rahn at Bank BPRS Bhakti Sumekar, the benefits obtained by the community and the impact of Rahn products on the economy of surrounding communities. This study uses qualitative methods because researchers want to obtain data or information as deeply as possible. Data collection techniques used were the method of observation, interviews and documentation. The informants in this study were the Director of Bank BPRS Bhakti Sumekar and the bank customer of the BPRS.
\end{abstract}

Keywords: Financing, Ar-Rahn, Gold Pawn

\section{INTRODUCTION}

In everyday life, society has a need to be fulfilled, both primary needs, secondary needs, and tertiary needs, even Lux's needs. But not all of these needs can be fulfilled for various reasons. The most classic reason for fulfilling these needs is the reason for funding. So not infrequently in order to meet these needs, someone must sell their property or make a loan of funds to other people or parties, even though people are often trapped in a loan shark (loan sharks) to fulfill all their needs. Islamic religion is complete and perfect and has laid down basic rules and rules in all aspects of human life, both in worship and muamalah (relations between beings). Everyone needs interaction with others to cover each other's needs and help between them. For this reason, we really need to know the rules of Islam in all aspects of our daily lives, including about social interaction with fellow humans, especially with regard to the transfer of property from one hand to another. Debt is sometimes unavoidable, even though lately there have been many phenomena of mistrust among humans, especially in this age. So people are urged to ask for guarantees of objects or valuables in lending their property. The existing reality cannot be denied, the proliferation of pawnshops, and other financial services, both those managed by the government and the private sector, are evidence of the fertility of the practice of financial services. But ironically, many Muslims have not known the beautiful and fair rules in Islam about this. Even though this case is not a new matter in their lives, they have long known this type of transaction. As a result, tyranny took place and consumed each other's possessions vanity.

On Madura Island, in one of the easternmost districts of Sumenep Regency, there is a large Islamic financial institution, namely PT. BPRS Bhakti Sumekar, so far, this Bank having its head office in the City of Sumenep has 12 Cash Office Services spread throughout Sumenep district, 1 Branch Office in Pamekasan Regency and 2 Cash Offices in Pamekasan district. They carry out their banking activities with a healthy concept of Sharia. Some of their products include Barokah Savings with Wadiah, Mudharabah Deposits, Mudharabah Financing, Murabahah Financing, Al Qardhul Hasan Financing, and others, as well as the most popular and phenomenal among Sumenep Regency communities, through gold pawn financing rahn). Shari'ah laws are rules that govern the way to worship, worship 
and others. And these rules are considered as the application of methods to certain events. Therefore, this is called the application of sharia, and not sharia itself. One form of muamalah that is easy to practice is rahn, in muamalah Fiqh, the pawn agreement is called rahn. The term rahn in language means "holding back". It means holding something back to guarantee debt. It can be stated that the pawnshop according to the provisions of Islamic Shari'a is a combination of the term pawn contained in the Civil Code, which is concerned with the object of a pawn agreement according to Islamic law which includes goods that have a property value, and are not questioned whether he is a moving or immovable object.

The definition of pawn of sharia (rahn) in language as expressed above is fixed, eternal, and guaranteed; while in the sense of the term is holding host a number of assets handed over in a right, and can be taken back a number of assets in question after repaying its debts. Rahn objects that are pawned, in the concept of Fiqh is a mandate that is in the murtahin (recipient of a pawn) that must always be maintained as well as possible. However, to maintain and care for the goods pawn is still good, of course, costs are needed, which of course the costs that arise are charged to the person who pawned or by using the goods pawn. In the case of the use of pledged goods, some scholars differ because the problem is very closely related to the nature of mortgage goods, which only serves as collateral for the debt of the pawning party. It's not too much if the researcher calls Rahn Bank's product PT. BPRS Bhakti Sumekar said in a popular and phenomenal way, why, because in the eyes of researchers who are also people, academics, as well as customers at the Bank, this product is very profitable, some of the benefits that the community receives are fast, practical, and reassure Fast because it is not too long for the process of realization of financing, Practical because the requirements they set on this product are very easy, just bring collateral in the form of gold and a valid identity card and visit their service office that serves this product. Reassuring because the source of funds comes from sources that are in accordance with sharia principles, even with the pawn process and contract practiced. And the most important thing is that the costs arising from the maintenance of pawned goods at the Bank are very affordable and relatively cheap and profitable for the community.

Thus, the Islamic financial system at Bank PT. BPRS Bhakti Sumekar is formulated from a combination of the principles of syar'i taken from the Koran and sunnah, and from the principles of tabi'i which are the result of the interpretation of human reason in dealing with economic problems such as other relevant economic principles. Financial system at Bank PT. BPRS Bhakti Sumekar is not only concerned with aspects of return (profit) and risk, but also contributes to considering Islamic values in it. In this case the pawning practices that are carried out are kept to the maximum extent possible to avoid business practices that contain elements of gharar (uncertainty), maisir and usury. Therefore, every operational implementation imposed in the practice of pawning at Bank PT. BPRS Bhakti Sumekar is consulted with Dewan Pengawas Syariah (DPS). The purpose and benefits of Rahn products at Bank PT. BPRS Bhakti Sumekar is providing financial services that are relatively fast and safe for the general public and at the same time foster profits based on good management principles. Therefore, Bank PT. BPRS Bhakti Sumekar through its Rahn products aims as follows:

- Also implement and support the implementation of government policies and programs in the national economy and development sector in general through the distribution of financing / loans based on mortgage law.

- Prevention of illicit practices, and other improper loans.

- Utilization of interest free pledges on Rahn products of PT. BPRS Bhakti Sumekar has the effect of a social security net because people who need funds urgently no longer get entangled in interest-based loans / financing.

- Helping people who need loan funds with easy conditions with a faster and safer process.

Rahn has a very large social function in the Islamic economic system, because it is not solely seeking profit, but more predominantly the nature of helping, certainly very different from the capitalist economic system which is all for profit or business, while the nature of help helps it is only a cover for popularizing itself in the eyes of the public. From the provisions above, it is very clear that the existence of Rahn Bank PT. BPRS Bhakti Sumekar has an important role, because it is not uncommon in life where we are often confronted with cash needs which are sometimes so urgent. Based on the phenomena that exist, researchers are very interested in studying the benefits of Rahn products for the economy of the surrounding community. The purpose of this study was to determine the implementation 
of Rahn's practices at PT. BPRS Bhakti Sumekar and to find out the benefits obtained by the community with the presence of Rahn products PT. BPRS Bhakti Sumekar.

\section{LITERATURE REVIEW}

\subsection{Islamic Bank}

In Law Number 10 of 1998 which was later amended by Act Number 21 of 2008 concerning Sharia Banking, it is stipulated that the main function of national banking is as an institution of collecting and channeling public funds in order to improve the standard of living of many people. In the Law, the principles and objectives of Islamic banking are explained to support the implementation of national development in order to improve justice, togetherness, and equitable distribution of people's welfare. Banking has an intermediation function, namely as a medium that connects parties that have excess funds with those who lack funds. Sharia Banking is everything that concerns Sharia Banks and Sharia Business Units, including institutions, business activities, and ways and processes in carrying out their business activities. (Law No. 21 of 2008).

In its history, Islamic banking is an early form of market economy and mercantilism, which some economists refer to as "Islamic Capitalism", has begun to develop between the 8th and 12th centuries. (Labib, 1969, 79:96). The monetary economy in that period was based on dinar currency which circulated widely at that time, which brought together regions that were previously economically independent. In the 20th century, the birth of Islamic banking was inseparable from the presence of two modern Islamic renaissance movements, namely neorevivalist and modernist movements. (Abdullah, 1996). Around the 1940s, in Pakistan and Malaysia there were efforts to manage nonconventional pilgrimage funds. Then in 1963, the Islamic Rural Bank was established in Mit Ghamr village in Cairo, Egypt. (Muhammad, 2001). Global Islamic banking is growing at a rate of 10-15\% per year, and shows signs of consistent growth in the future. Report from the International Association of Islamic Banks and the analysis of Prof. Khursid Ahmad said that until 1999 there were more than 200 Islamic financial institutions operating throughout the world, namely in countries with a majority Muslim population and other countries in Europe, Australia and America. (Ahmad, 1999). It is estimated that there are more than USD 822,000,000,000 assets worldwide that are managed according to sharia principles, according to the 1999 analysis of The Economist magazine. This covers approximately $0.5 \%$ of the total estimated world assets in 2005. (Slater, 2007). Analysis of the CIMB Group Parent Company states that Islamic finance is the fastest growing segment in the global financial system, and sales of Islamic bonds are expected to increase 24 percent to reach USD 25 billion in 2010 .

\subsection{Principles of Sharia Banks}

The principle of shari'ah banking is an agreement based on Islamic law between banks and other parties (muamalah) for depositing funds and financing business activities or other activities in accordance with shari'ah. Some of the legal principles adopted by the Shari'ah banking system include:

- Payments for loans with different values than loan values with predetermined values are not allowed.

- The fund giver must share the profits and losses as a result of the results of the institution's business that borrows funds.

- Islam does not allow "making money from money".

- Money is only a medium of exchange and not a commodity because it has no intrinsic value.

- The element of ghahar (uncertainty, speculation) is not permitted.

- Investments may only be given to businesses that are not prohibited in Islam.

\subsection{Ar-Rahn (Pawn)}

According to the large Indonesian dictionary, Pawn means a loan borrowed money within a certain time limit by handing over the goods as dependents, if the deadline is not repaid, the pawn of goods becomes the right of the lender. Or pawn can also mean the goods delivered as debt liabilities. Then the understanding of the next mortgage according to the large Indonesian dictionary is a short-term 
loan with securities guaranteed that is valid for three months and can be extended whenever it is not stopped by one of the parties concerned.

Ar-Rahn is a mortgage transaction that is getting a loan by giving a number of guarantees to the lender in accordance with sharia principles. The owner of the goods / debts is called Rahin (who pawns), the recipient of the goods / pledge is called Murtahin, and the goods are called Ruhn or Marhun. According to Bank Indonesia (1996), Rahn is a contract for delivering goods / assets from customers to banks as collateral for part or all of the debt. According to Syara 'Rahn is the detention of an item with rights so that it can be used as payment for the item. Each element in Rahn has the requirements that must be fulfilled in order to achieve the validity of the transaction, both Rahin, Murtahin, Marhun Bih, and Marhun, what has to be fulfilled must be determined.

While the pillars of rahn that must be fulfilled to maintain the validity of this transaction are:

1. Sighat or Akad or Ijab Qabul.

2. Aqid (who pawned or Rahin and who received a pawn or Murtahin).

3. Pawn goods or goods used as collateral (Marhun). The Hanafiyah Ulama requires Marhun with the following criteria (Al-Kasani, Al-Bada 'i, Ash-Shana 'i fi Tartib Asy-Syara 'i, juz VI Hal 135: 140):

- Can be traded

- Useful

- Clear

- belongs to Rahin

- Can be submitted

- Not united with other assets

- Hold / controlled by Rahin

- Fixed or movable assets.

4. Debt (Marhun Bih), provided that the debt is directly given by Murtahin to Rahin.

In the case of taking the benefits of Marhun by Murtahin, the ulema's opinion was that murtahin should not take advantage of the mortgages, even though rahn permitted it, because this included debt that could attract benefits, so that if used included usury. (Suhendi, Hendi. 2010. Muamalah Fiqh. Jakarta: Rajawali Press Hal 108). In contrast to Hanabilah and Hanafiyah who allow the utilization of marhun with permission from rahin. Regarding the cost of treatment for marhun, fuqaha agrees on matters relating to marhun the essence is rahin rights. Even the cost of treatment. But it will be different when the marhun is an animal, for example a dairy cow. Murtahin in this case is allowed to take milk from the cow in return for treatment, because the cost of care is not requested from rahin. As in a hadith: "animals can be ridden because of financing when pawned, animals may be taken milk to drink because of the financing if pawned for people who hold and drink it must provide costs." (AlKahlani, Subul As-Salam, p. 51) .

Ijarah is a contract for distributing funds for the transfer of usufructuary rights (benefits) for an item within a certain period of time with lease payments (ujrah), between finance companies as leasing agents (mu'ajjir) with tenants (musta'jir) without being transferred . (Andri Soemitra, MA. "Islamic Banks and Financial Institutions". Jakarta: Kencana 2009 Ed.1 Cet.1 h.349).

Ijarah can also be interpreted as a contract between the bank (mu'ajjir) and the customer (mutta'jir) to rent an item / object for rent owned by the bank and the bank receives service fees for the goods rented, and ends with the purchase of the object for rent by the customer. The sharia foundation of this contract is DSN-MUI fatwa No.09 / DSN-MUI / IV / 2000 concerning financing of Ijarah.

The basis of the Ijarah law includes the Koran Surat Al-Baqarah verse 233: "And if you want your child to be spoiled by someone else, then there is no $\sin$ for you if you give a payment according to the right. fear Allah and know that Allah sees what you are doing. "(QS.al-Baqarah: 233) and AlHadist:" Give a reward to the person you employ before drying their sweat. "(Narrated by Abu Ya ' he, Ibn Majah, at-Thabrani and Tirmidhi). 


\section{Pillars of Ijarah Include}

- Mu'jar (person / item rented).

- Musta'jir (the person who hires).

- Sighat (ijab and qabul).

- Wages and benefits.

\section{Ijarah Requirements Include}

1. Both people who are mindful must be balanced and understanding.

2. Declare his willingness to do the ijarah contract.

3. The benefits of being an ijarah object must be known perfectly.

4. The ijarah object may be submitted and used directly and without blemish.

5. The object of ijarah is something that is permitted by syara 'and is something that can be rented out.

6. What is leased is not an obligation for tenants.

7. Wages / rent in the contract must be clear, certain and something that is worth assets.

\section{RESEARCH METHODS}

This study uses a qualitative method. this method would certainly be very appropriate to produce indepth information regarding the practice of implementation, the benefits of Rahn's products PT. BPRS Bhakti Sumekar. In the first stage, the researcher will describe all information obtained. Next, the researcher will reduce all information obtained in the first stage. The third stage, the researcher will analyze the information that has been obtained and then the researcher will draw conclusions from the information obtained in the field. This study uses a purposive sampling technique in sampling which is called a resource person (informant). In accordance with the focus of the study, the informants (informants) in this study were:

\section{- Director of PT. BPRS Bhakti Sumekar}

- Customers of PT. BPRS Bhakti Sumekar who used Rahn (Pawn) products.

This study uses primary data and secondary data. The technique of data collection uses the method of observation, interviews and documentation. Observations are intended to determine the process of implementing rahn (pawn) at PT. BPRS Bhakti Sumekar. Structured interviews were conducted by researchers to obtain information from resource persons namely Director of Bank PT. BPRS Bhakti Sumekar and Rahn Bank Customers PT. BPRS Bhakti Sumekar.

\subsection{Research Result}

Data collection in this study was obtained through interviews with several resource persons who were considered capable of providing information about Rahn BPRS Bhakti Sumekar Sumenep products. To find out the implementation process of Rahn, the researcher conducted an interview with the BPRS Bhakti Sumekar Sumenep namely Mr. Cahya Wiratama as Operations Director. The interview was held on Wednesday, March 25 2015, at 11.00 WIB at the BPRS Bhakti Sumekar Sumenep Head Office. The results of the interview are as follows:

"Gold pawning products are the most popular products for customers and become a mainstay product here, there are many advantages that we offer from this gold pawn product".

"We provide financing to the community with gold collateral, we here do not ask for profit sharing but we only charge safekeeping and maintenance fees, the cost is very cheap, the system calculates costs per day so it does not harm the customer. Our concept here helps, so we do not charge fees too heavy for customers ".

"Gold pawning at the SRB has been stopped for five months because the rules of the BI and OJK, namely in the cash office, should not be realized. We want to make it easier for the community to open a cash office in several sub-districts but the rules are not in line with our wishes. With a long debate, 
the gold pawning was finally reopened with the requisite conditions to be carried out at the head office. With this rule, it slows down the mortgage process at the SRB especially those in the cash office. If you need it quickly, usually the customer goes directly to the head office. "

"This bank chooses the area and it is certain that the government is really down to overcome this by increasing the injection of capital. To open a new branch we need a deposit of 370 million and thank God the government is very supportive of our plan."

"The biggest contribution from the product of gold pawning, the transactions carried out are quite large and the turnover is fast. Every day there is a direct repayment transaction for the financing and there is a new disbursement".

Interviews were also conducted with 5 Rahn BPRS Bhakti Sumekar Sumenep customers. The first information was Mr. Kholis the owner of BMT Ar-Rahman in Ganding Village, Ganding District. The interview was conducted on Sunday, March 8, 2015 at 09.00 WIB. Following are the results of interviews of researchers with Mr. Kholis.

"I have been a customer at BPRS Bhakti Sumekar Sumenep since 2003, it was me as an employee at Koperasi Pondok. In 2003, I got my own business, BMT Ar-Rahman, who received eman pawn from the community around the house ". "Initially I was a Pegadaian customer, when I went to town I saw a BPRS Bhakti Sumekar Sumenep signpost, I tried to ask questions and consult with employees and I tried. Since then I have been a customer at BPRS Bhakti Sumekar Sumenep".

"Already, I have a business so I look for information and compare between one another, I compare the cost calculation system, after I compare it turns out that it is the cheapest BPRS Bhakti Sumekar Sumenep and the process is not complicated".

"In BPRS Bhakti Sumekar Sumenep the cost is calculated per day so that I benefit, for example, I only pawned gold for a few days, if BSM calculates costs per 15 days (half a month), Sharia Pegadaian calculations per 10 days, the cost calculation at Pegadaian is the same as BSM that is per 15 days. In BMT NU the calculation is per day. The system of calculating costs, costs (costs) in BPRS Bhakti Sumekar Sumenep is the cheapest ".

"I must go to the Guluk-guluk office SRB every day. If I need it quickly, I immediately come to the head office in Sumenep. Since I stopped selling, if I put the items in the cash office for a long time, for example, when I arrived in the morning, I could receive money after a break, but if in the center directly, I don't know much about the new rules set by OJK.

"There has been no intention to move, even though the process is so, but my choice remains with BPRS Bhakti Sumekar Sumenep, because if compared to the others BPRS is cheaper and easier".

"Disappointed dizzy too, at that time my business (BMT) was also closed because if I taruk in pawnshops or the other expensive pity my customers, 5 months I closed BMT, sorry for the people who need money but my capital was also thinning at that time, but thank God now it's been opened even though the process isn't as fast as it used to be if at the cash office ".

The second interview was conducted with Pak Supatno, on Saturday, March 14, 2015, at 6:30 a.m. WIB in Saronggi Village, Saronggi District. The results of the interview are as follows:

"I pawned gold in the BPRS since the beginning of 2010, at that time I needed fast money for business capital, he said, cheap and easy BPRS, it turned out to be true".

"Once the other but expensive, I know about BPRS from friends and I come directly to the office in Bluto. Usually if you want to buy materials and goods that have not been sent, it is not certain but clearly every month you go to the BPRS, I need money for a little while, because the cost calculation system in BPRS per day is cheaper if I only pawn, when the PPRS is closed I need a lot of profit is opened again ".

The third informant was Mrs. Ratna, the interview was conducted on Saturday, March 14, 2015 at 10.00 WIB at Paragaan. The results of the interview are as follows:

"Since the opening of the BPRS office here, I have become a customer, quite a long time. The story at that time was that I needed capital that only gold was available to sell, unfortunately fortunately there was a mortgage in the BPRS, in other places it was expensive ". 
"Because it is only for business capital, I usually have 2 months of gold pawning, 3 weeks at the earliest, fortunately at BPRS it is cheap and calculated per day so it is cheaper and lighter for me, if I need fast money, I will go to BPRS".

"Once the SRB was closed on the gate, it was forced at that time but what else can I do, just when it needs it, it is expensive in other places, if the SRB is cheap, and fast".

The next informant was Pak Zeini, a fisherman, the interview was conducted in Dungkek, Sunday, March 152015 at 10:00 WIB. The results of the interview are as follows:

"Since I opened the office here, I have become a BPRS sermon, very helpful for me and the people here, especially when the catch is a little. When you need capital to create a chart, usually gold is pawned and redeemed if the distribution of the results of the chart, if not like that can get money from where, played and like that continues ".

"I have compared with the others, but in the cheapest BPRS, I do not really understand the calculations, but when I try elsewhere with the same amount and time it turns out the cost is more expensive".

"Depends on money, if I have money I redeem it but if it doesn't, it's not redeemed, my income will not depend on the catch".

"The pawning time at the BPRS was closed, but fortunately at that time I only redeemed gold, and fortunately when I needed the mortgage I was opened again".

"Not as fast as the first process but not a problem for me".

"It really helps me because I can get money quickly, easily and cheaply, which is the most important, many of them receive gold pawning but cheap ones only in BPRS".

"One time I forgot that it fell out, but the BPRS called to let me know it had fallen out and had to be redeemed, because I did not have money so I extended it. That was what I liked, there was a notification and the goods were not immediately confiscated."

The last informant was Mrs. Nanik, the interview was conducted on Sunday, March 15, 2015 at 15.00 WIB in Kalianget Timur Village, Kalianget District.

"I just need money suddenly, usually pawning gold to the BPRS. In 2005 there was still no, I usually went directly to the head office in Sumenep. But now there is already closer here.

"The name is there are people who need it, to send children to college but not yet pay, to increase capital ever"

"Depends on money, if there is usually I will immediately redeem it, but if there isn't already it will be a long time to be redeemed."

"BPRS is cheaper, I have been somewhere else".

\section{DISCUSSION}

\subsection{Gold Pawn (Ar-Rahn)}

Gold Pawn was one of the mainstay products of BPRS Bhakti Sumekar Sumenep. Financing services for all purposes for individuals using sharia principles (Ar Rahn) based on the calculation of daily storage and maintenance services on collateral.

Gold pawns were in great demand by people who need funds fast, easy and cheap. Fast because customers do not need long to get cash for less than 1 hour they have already received cash. Easy because it was enough to bring the specified requirements, namely a photocopy of Identity Card (KTP or SIM), guarantee in the form of gold. 4 months gold pawning period and can be extended 1 time. Cheap because the calculation of gold pawning costs with a daily system was Rp. 6 per day. That means Rp. 6 per day per Rp. 10,000, - the estimated value of the guarantee, for example the estimated value of Rp. 1,000,000, - the return value of its storage and maintenance services was Rp. 600,- per day.

The process of conducting gold pawning (Rahn) in BPRS Bhakti Sumekar Sumenep, as follows:

- The customer comes with gold and an identity card (KTP or SIM); 
- Admin registers for the customer;

- Admin input customer data and collateral, for example 1 necklace;

- The system will give a print out of the item (gold);

- Print out and guarantee was submitted to the estimator to determine the weight and grade of gold;

- After the print out was filled in the data content and weight by the estimator, then the print out was returned to the admin to determine the nominal that can be received by the customer;

- After the customer agrees with the loan to be received, the admin will proceed to the next process, namely requesting the approval of the mortgage (authorization) to the authority;

- After receiving authorization from the boss then the admin will continue the process such as:

$>$ Print out a pawn agreement

$>$ Print transaction agreement

- Number of gold pawn financing for the customer.

Finally, after all administrative processes are completed and have obtained a financing account number, the account number is ready to be realized at the teller and money can be received at the teller.

\subsection{Benefits of Gold Pawn Products}

Gold Pawn in BPRS Bhakti Sumekar Sumenep was a financing service for all needs for individuals using sharia principles (Ar-Rahn) based on the calculation of daily storage and maintenance services on collateral. Gold pawn was one alternative to get money quickly, easily and cheaply. By providing collateral in the form of gold, we can get cash quickly.

From the results of interviews conducted by researchers, it was known that many of the benefits obtained by customers by pawning gold in BPRS Bhakti Sumekar Sumenep, include:

- Gold pawning at the SRB does not apply profit-sharing benefits because this product was created to help people in need of funds in the short term. Customers were only required to pay off the loan and be charged the cost of renting safekeeping and gold maintenance called ujroh;

- The procedure for pawning gold in the BPRS was relatively easy and not complicated. Customers who need funds can quickly contact the head office in Sumenep, branch offices in Pamekasan and cash offices;

- Guaranteed security goods (gold) guaranteed by BPRS Bhakti Sumekar Sumenep;

The cost calculation system implemented in BPRS Bhakti Sumekar Sumenep was cheaper than the others because the system calculates per day was Rp. 6 per day. That means Rp. 6 per day per Rp. 10,000 , - the estimated value of the guarantee, for example the estimated value of Rp. 1,000,000, - the return value of its storage and maintenance services was Rp. 600, - per day.

Financing to Value (FTV) was a comparison between the amount of financing received by the Customer and the value of gold pledged by the Customer to the Bank. The determination of Financing to Value (FTV) for gold pawn products at BPRS Bhakti Sumekar Sumenep was 90\%. On 3 January 2015 , Customer bring gold to be pawned in the form of a bracelet with a grade of $80 \%$ and weighing 20 grams. If the price of gold in the market was IDR 300,000, then the money that the customer can receive it;

Estimates $=$ levels $\mathrm{x}$ weight of gold $\mathrm{x}$ Price of gold

$$
\begin{aligned}
& =80 \% \times 20 \text { gram } \times 300.000,- \\
& =\text { Rp. } 4.800 .000
\end{aligned}
$$

Financing $=$ Estimated $\times 90 \%$

$$
\begin{aligned}
& =\text { Rp. } 4.800 .000 \times 90 \% \\
& =\text { Rp. } 4.320 .000,^{-}
\end{aligned}
$$


In mid-2014, pawn emasa activities at BPRS Bhakti Sumekar Sumenep were stopped by the Financial Services Authority (OJK) on the grounds that the cash office was not permitted to carry out financing realization. This happened for five months, at the end of 2014 the gold pawn was opened again but with a different process. After the gold pawn was reopened, the realization must be carried out at the head office, so that the process was rather long. According to the OJK, the cash office must not carry out financing realization, the cash office was only for saving and withdrawing savings. The presence of gold pawning at BPRS Bhakti Sumekar Sumenep greatly helps people who need short-term funds. Gold pawn was in great demand and an alternative. Most BPRS Bhakti Sumekar gold pawn customers are business owners who need short-term funds to turn their capital. Financing provided through gold pawning was classified as short-term financing (less than one year), so it was very suitable to meet needs that were urgent not suitable for long-term investment. Gold pawn products contain risks due to fluctuations in gold prices, namely market risk associated with falling prices gold. Many benefits were felt by the community with the presence of BPRS Bhakti Sumekar Sumenep gold pawning products. This gold pawn service was cheap, easy and fast. It was cheap in terms of costs so that it was easy for customers. Easy and fast from the process so that customers can get cash quickly.

The Impact of Gold Pawn For the Community Economy with the existence of gold pawning products BPRS Bhakti Sumekar Sumenep greatly helped the economy of the people in Sumenep. Gold pawning assets were individuals, the reason for pawning gold was to fulfill children's educational needs, turnover of business capital, medical treatment, and others. From the results of the interview it was known that at the time of the gold pawning the BPRS was stopped by the customers, especially the business actors who were confused when they needed additional capital. Some of them were not operating, there were also those who have to be willing to pay high fees to get funds. This proves that the impact of gold pawning on the economy of society was very large.

\section{CONCLUSION AND SUGGESTION}

\subsection{Conclusion}

- The presence of BPRS Bhakti Sumekar Sumenep gold pawning products was very helpful for people who need fast funds at cheap and easy costs.

- BPRS Bhakti Sumekar Sumenep gold pawning products provide many benefits for customers.

- BPRS Bhakti Sumekar Sumenep's gold pawning products had a profound effect on the economy of the community. This can be felt when the BPRS Bhakti Sumekar Sumenep pawning products were stopped for five months.

\subsection{Suggestion}

- For PT. BPRS Bhakti Sumekar Sumenep immediately opened a branch office to improve service to the community.

- For the next research, namely similar research can be done by focusing on one area so that the impact felt by the community can be clearly seen. In addition, informants or resource persons were added to obtain representative data.

\section{REFERENCES}

[1] Soemitra,Andri, MA.2009. Bank dan Lembaga Keuangan Syariah”. Ed.1 Cet.1 Jakarta: Kencana.

[2] Sugiono. 2010. Metode Penelitian Kuantitatif Kualitatif dan R\&D. Bandung: Alfabeta.

[3] Suhendi, Hendi. 2010. Fiqh Muamalah. Jakarta: Rajawali Pers

[4] Undang-undang Nomor 21 Tahun 2008 tentang Perbankan Syariah

[5] www.wikipedia.org/wiki/islam_menurut_negara (6 September 2014)

Citation: Dedy Arfiyanto, et.al. "Assessing the Benefits of the BPRS Bank Products Well Variety for the Economy of the Community " International Journal of Managerial Studies and Research (IJMSR), vol 7, no. 3, 2019, pp. 29-37. doi: http://dx.doi.org/10.20431/2349-0349.0703004.

Copyright: (C) 2019 Authors. This is an open-access article distributed under the terms of the Creative Commons Attribution License, which permits unrestricted use, distribution, and reproduction in any medium, provided the original author and source are credited. 